\title{
Comparative Evaluation of Growth Media for the Cultivation of Fungal Cultures
} Chinyerum Gloria Ikechi-Nwogu ${ }^{1 *}$ and Edith Nkem Elenwo ${ }^{2}$

${ }^{1}$ Department of Plant Science \& Biotechnology Faculty of Science, University of Port Harcourt, Nigeria ${ }^{2}$ Department of Plant Science and Biotechnology, University of Port Harcourt, Rivers State, Nigeria

\begin{abstract}
An evaluation was carried out on some growth media for the cultivation of fungal cultures. Fungi such as Aspergillus niger, Aspergillus flavus, Penicillium chrysogenum, Aspergillus terreus, Aspergillus glaucus, Fusarium oxysporium, and Rhizopus stolonifer were isolated from food materials using Standard Blotter Method. Pure cultures were obtained and transferred into Potato Dextrose, Soybean Dextrose, Sawdust Sucrose, Ofor (Detarium macrocarpum) Sucrose and Groundnut Dextrose Broths respectively, to screen their suitability for culturing fungi. After incubation at $27 \pm 1^{\circ} \mathrm{C}$ for 7 days, the organisms were harvested, weighed with a weighing balance to measure their growth rate. The mean values for all the organisms in Soybean broth except Fusarium oxysporium, were significantly $(P \leq 0.05)$ higher than those of Groundnut Dextrose, Ofor (Detarium macrocarpum) Sucrose Broth, Sawdust Sucrose Broth and Potato Dextrose Broth. Soybean Dextrose Broth, performed better than other broths probably because it contains more vitamins and minerals vital to fungal growth.
\end{abstract}

Keywords: Growth media; Fungal cultures; Cultivation

\section{Introduction}

Fungi are members of the kingdom Fungi and are eukaryotes (i.e. organisms whose cells contain complex structures enclosed within membranes). It can also be referred to as organisms that have nuclei in their cells. The Fungi are classified as a kingdom that is separate from bacteria, plants and animals [1].

Fungi are heterotrophic organisms (meaning that they require external sources of organic compounds for food). Fungi grow as multicellular filaments called hyphae forming a mycelium; some fungal species also grow as single cells. They reproduce sexually and asexually and it is commonly via spores, produced on specialized structures or in fruiting bodies. Some species have lost the ability to form specialized reproductive structures, and propagate solely by vegetative growth. Examples of fungi are yeasts, molds and mushrooms. The fungi are more closely related to animals than plants, yet the discipline of biology devoted to the study of fungi, known as Mycology, often falls under a branch of botany [2].

Occurring worldwide, most fungi are largely invisible to the naked eye, they grow in a wide range of habitats, including deserts or areas with high salt concentration or ionizing radiation, water, soil, human, plants and animals as well as in deep sea sediments. Some can survive the intense Ultra Violet Radiation encountered during space travel. Fungi perform an essential role in all ecosystems in decomposing organic matter and are indispensable in nutrient cycling and exchange. Some fungi become noticeable when fruiting, either as mushrooms or molds.

Many fungi are used as a direct source of food, such as mushrooms and truffles and in fermentation of various food products, such as: wine, beer, and soy sauce. More recently, fungi are being used as sources of antibiotics in medicine and various enzymes, such as cellulases, pectinases, and proteases, important for industrial use or as active ingredients of detergents. Many fungi produce bioactive compounds called mycotoxins, such as alkaloids and polyketides that are toxic to animals including humans. Some fungi are used recreationally or in traditional ceremonies as a source of psychotropic compounds. Several species of the fungi are significant pathogens of humans and other animals. Losses due to fungi diseases of crops and food spoilage caused by fungi can have a large impact on human food supply and local economies.

\section{Fungi are important experimental organisms [3]}

$$
\begin{aligned}
& >\text { They are easily cultured } \\
& >\text { Occupy little space } \\
& >\text { Multiply rapidly } \\
& >\text { Have short life cycle } \\
& >\text { Used to study mycrobial assays of vitamins and amino acids. }
\end{aligned}
$$

\section{Media}

A substance on which a mould is grown on in the laboratory is called a medium and the mould growing on it, a culture. Culture media can be solid or liquid. For the purposes of identification, solid culture media are usually more useful, as they allow the mould to sporulate more easily [4].

\section{Materials and Methods}

\section{Materials}

Food items: Bread, raw groundnut seed (Arachis hypogaea), healthy Detarium macrocarpum (ground ofor), oranges (Citrus sinensis), whole water melon (Citrullus lanatus), paw paw fruit (Carica papaya), corn (Zea mays) and common bean seeds (Phaseolus vulgaris). These food materials supported the growth of the fungi represented here.

${ }^{*}$ Corresponding author: Chinyerum Gloria Ikechi - Nwogu, Department of Plant Science \& Biotechnology Faculty of Science, University of Port Harcourt, Nigeria, Tel: +2348032325098; E-mail: Chinyerum.nwogu@yahoo.com

Received September 12, 2012; Accepted October 27, 2012; Published October 30, 2012

Citation: Ikechi-Nwogu CG, Elenwo EN (2012) Comparative Evaluation of Growth Media for the Cultivation of Fungal Cultures. J Plant Pathol Microb 3:139. doi:10.4172/2157-7471.1000139

Copyright: (c) 2012 Ikechi-Nwogu CG, et al. This is an open-access article distributed under the terms of the Creative Commons Attribution License, which permits unrestricted use, distribution, and reproduction in any medium, provided the original author and source are credited. 
Materials used for the preparation of media: Raw groundnut, Ground Ofor (Detarium macrocarpum) and Soybean seeds, Potato and sawdust.

Glass ware and other mycological laboratory equipment were used.

\section{Methods}

Isolation: Fungi were isolated from food materials using Standard Blotter Method. In this method, petri dishes were lined with 3 layers of sterilized $9 \mathrm{~cm}$ filter paper. Sterilized distilled water was used to wet them and excess water poured out. The food materials used were sorted to remove diseased ones, then soaked in $70 \%$ ethanol for 5 minutes and rinsed twice in sterilized distilled water; after which they were placed in Petri dishes equidistantly and incubated at $25^{\circ} \mathrm{C}$ in the laboratory for 3-7 days. The following fungi such as; Aspergillus niger, Van Tieghem; Aspergillus flavus, Johann Heinrich Friedrich Link; Penicillium chrysogenum, Thom; (previously known as Penicillium notatum); Aspergillus terreus, Thom; Aspergillus glaucus, Link; Fusarium oxysporium, Schltdl; and Rhizopus stolonifer (Ehrenb.: Fr.) Vuill; were found growing on the food materials. They were isolated and sub-cultured on the different culture media from which pure cultures were made and maintained on these media at $27 \pm 1^{\circ} \mathrm{C}$ and preserved in the refrigerator.

\section{Preparation of media}

Soybean and groundnut dextrose broth: Composition: Soybean-200 g, Dextrose: 20 g, water: 1liter.

Method of preparation: The required quantity ( $200 \mathrm{~g})$ of soybean (Glycine max) and Groundnut (Arachis hypogaea) was sorted separately to remove stones and dirt, then weighed and washed, transferred into a pot containing one liter of water and placed on a Bunsen burner to boil until soft and strained through a sieve. The liquid obtained was transferred into 1 liter $/ 1000 \mathrm{ml}$ measuring cylinder and $20 \mathrm{~g}$ of dextrose was dissolved and added.

Potato Dextrose Broth: Composition: Potatoes-200 g, Dextrose $20 \mathrm{~g}$, water-1 liter.

Method of preparation: Irish Potato (Solanum tuberosum) was peeled; required quantity $(200 \mathrm{~g})$ weighed, washed and cut in tiny cubes. It was then transferred into a pot containing one liter of water and placed on a bunsen burner to boil until soft enough to mash. After mashing, it was squeezed through a sieve to obtain the pulp which was transferred into a 1 liter/1000 ml measuring cylinder, $20 \mathrm{~g}$ of dextrose was dissolved and added [5].

Sawdust Sucrose Broth: Composition: Sawdust-200 g, Dextrose-20 g, water-1 liter.

Method of preparation: The required quantity (200 g) of saw dust was weighed, boiled until the water colour changed from clear white to dark brown after which, it was strained through a sieve. The liquid obtained was transferred into 1 liter/1000 $\mathrm{ml}$ measuring cylinder and $20 \mathrm{~g}$ of sucrose was dissolved and added.

Ofor Sucrose Broth: Composition: Ofor (Detarium macrocarpum)-200 g, Dextrose-20 g, Water I liter.

Method of preparation: The required quantity $(200 \mathrm{~g})$ of boiled Ofor (Detarium macrocarpum) fruits were weighed, dissolved in hot water then transferred into 1 liter $/ 1000 \mathrm{ml}$ measuring cylinder and $20 \mathrm{~g}$ of sucrose was also dissolved and added.

The entire medium was made up to one liter, dispensed into 250 $\mathrm{ml}$ flasks, plugged with cotton wool and foil and sterilized with an autoclave at $126^{\circ} \mathrm{C}$ and 15 psi for 20 minutes. It was allowed to cool and 3 drops of $25 \%$ lactic acid was added [6].

Preparation of Agar Slants: About $40 \mathrm{ml}$ of the already prepared potato Dextrose Agar was poured into Mc Cartney bottle which had been sterilized at $15 \mathrm{psi}$ and placed in a slanting position on the bench to solidify. The different fungi were removed from the edge of the growing cultural using a $3 \mathrm{~mm}$ cork borer and placed faced down at the centre of the agar slant. Inoculated slants were incubated at $27 \pm$ $1^{\circ} \mathrm{C}$ for 4-7 days.

\section{Inoculation}

The already prepared media was allowed to cool, lactic acid added to inhibit the growth of unwanted microorganisms. The lactic acid was not added before autoclaving to avoid denaturization. The media were dispensed into petri dishes (for solid media), flasks (for broth) and Mc Cartney bottles (for slants) and sealed.

The culture was allowed to grow in a protected place that has as little air movement as possible.

Evaluation of fungi growth: liquid media was employed to recover the entire fungi colony. The organisms were grown in three replicates in a conical flask. They were all harvested by filtering into a dry sterile filter paper, weighed using an electronic weighing balance and their dry weight measurement collected were subjected to statistical analyses using SAS and mean values were obtained.

\section{Results}

The following results were obtained after screening the growth media for their suitability for culturing different fungi species.

\section{Evaluating the organisms}

The Soybean Dextrose Broth, showed growth in which Aspergillus niger had the highest growth followed by Rhizopus stolonifer, Aspergillus flavus, Aspergillus terreus, Penicillium chrysogenum, Aspergillus glaucus and Fusarium oxysporium in that order (Table 1). While in Groundnut Dextrose Broth, Rhizopus stolonifer had the best growth followed by Aspergillus niger, Aspergillus flavus, Aspergillus terreus, Aspergillus glaucus, Penicillium chrysogenum and Fusarium oxysporium. Also in Potato Dextrose Broth, Aspergillus niger had the best growth followed by Aspergillus flavus, Aspergillus glaucus, Penicillium chrysogenum, Aspergillus terreus, Fusarium oxysporium and Rhizopus stolonifer.

The organisms in Sawdust Sucrose and Ofor (Detarium macrocarpum) Sucrose Broths had the poorest growth. The poor growths were evident in Rhizopus stolonifer and Aspergillus flavus. Ofor (Detarium macrocarpum) did not encourage much fungal growth but it had more growth than sawdust.

Looking at the overall best organism, Aspergillus niger is considered because, it performed better than others. Comparatively, Aspergillus niger was best followed by Aspergillus flavus and Aspergillus glaucus which had equal growth followed by Aspergillus terreus, Penicillium chrysogenum, Rhizopus stolonifer and Fusarium oxysporium.

Evaluating the media: From the result obtained in figure 1, it is evident that the organism performed better in Soybean Dextrose Broth, followed by Groundnut Dextrose Broth, Potato Dextrose Broth, Sawdust Sucrose Broth and Ofor (Detarium macrocarpum) Sucrose Broth, while in figure 2, the organisms had the best growth in Soybean Dextrose Broth, followed by Groundnut Dextrose Broth, 


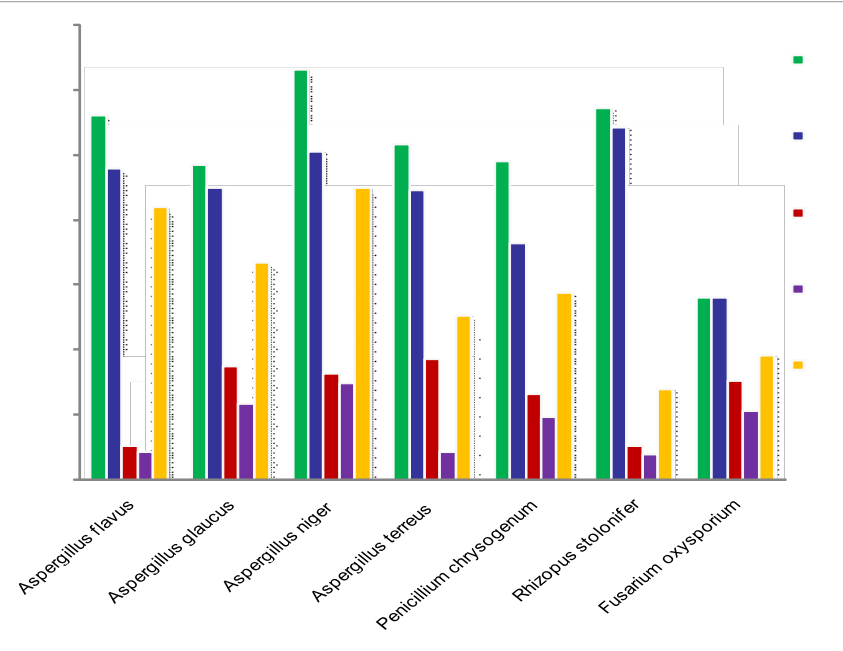

Figure 1: Graph showing the mean value of fungi in different growth media.

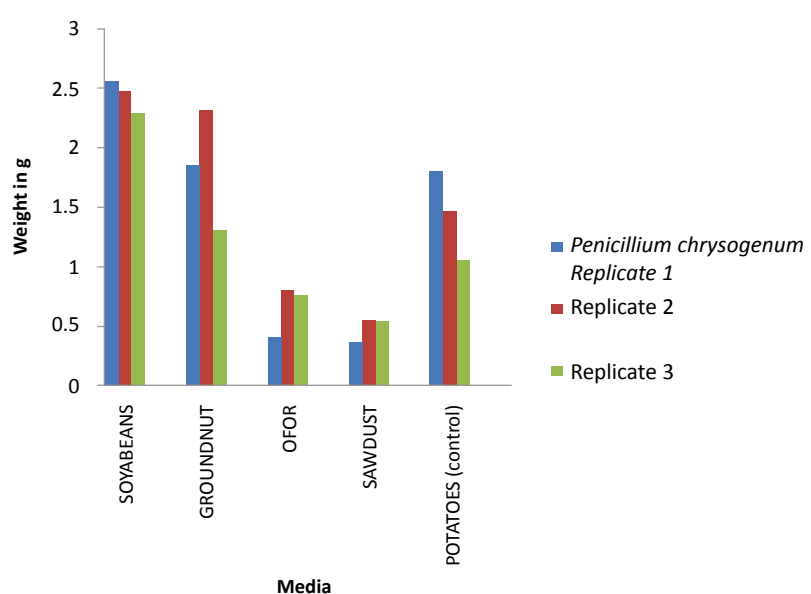

Figure 2: Graph showing the growth of Penicillium chrysogenum in different media.

Potato Dextrose Broth, Sawdust Sucrose Broth and Ofor (Detarium macrocarpum) Sucrose Broth.

Interpreting the result in figure 1 the mean value of fungi in different growth media, Aspergillus niger grew best in soybean broth compare to other organisms. Rhizopus stolonifer was the second best followed by A flavus, A terreus, while Fusarium oxysporium had equal growth in soybean and groundnut broth. In groundnut broth, Rhizopus stolonifer had the best growth followed by Aspergillus niger, A flavus, A glaucus, A terreus and Penicillium chrysogenum while in potato dextrose broth, Aspergillus niger was the best followed by A flavus, $A$ glaucus, Penicillium chrysogenum, A terreus, Fusarium oxysporium and Rhizopus stolonifer.

The significant difference of the performance of the organisms were examined and it was noticed that in soybeans broth, there is no significant $(\mathrm{P} \leq 0.05)$ difference between Aspergillus niger, Rhizopus stolonifer, A flavus, A terreus, A glaucus and Penicillium chrysogenum. But they are significantly $(\mathrm{P} \leq 0.05)$ higher than Fusarium oxysporium. In groundnut broth, Rhizopus stolonifer, is not significantly $(\mathrm{P} \leq 0.05)$ different from Aspergillus niger, A flavus, A terreus and A glaucus but it is significantly $(\mathrm{P} \leq 0.05)$ higher than Penicillium chrysogenum and Fusarium oxysporium. And there is also no significant $(\mathrm{P} \leq 0.05)$ difference between Penicillium chrysogenum and Fusarium oxysporium. There is no difference between Aspergillus niger, A flavus, A terreus, A glaucus and Fusarium oxysporium. In Ofor (Detarium macrocarpum) broth, there is no significant $(\mathrm{P} \leq 0.05)$ difference between Aspergillus niger, A terreus, Fusarium oxysporium and A glaucus. But they are significantly $(\mathrm{P} \leq 0.05)$ higher than Penicillium chrysogenum, Aspergillus flavus and Rhizopus stolonifer. But Aspergillus flavus and Rhizopus stolonifer are significantly $(\mathrm{P} \leq 0.05)$ lower than Penicillium chrysogenum. In sawdust broth, Aspergillus niger and A glaucus are significantly $(\mathrm{P} \leq 0.05)$ higher than Penicillium chrysogenum and Fusarium oxysporium which are also significantly $(\mathrm{P} \leq 0.05)$ higher than A flavus, A terreus and Rhizopus stolonifer. In potatoe broth, there is no significant $(\mathrm{P} \leq 0.05)$ difference between Aspergillus niger and $A$ flavus but they are significantly $(\mathrm{P} \leq 0.05)$ higher than others (Table 2$)$.

The mean values in Soybeans Dextrose Broth, Groundnut Dextrose and Potato Dextrose Broth, are significantly $(\mathrm{P} \leq 0.05)$ higher than those in Sawdust and Ofor (Detarium macrocarpum) Sucrose Broth. The mean value obtained from all the organisms in the different broth are as follows; For Aspergillus flavus: Soybeans Dextrose Broth (2.79), Groundnut Dextrose (2.39), Ofor (Detarium macrocarpum) Sucrose Broth (0.26), Sawdust Sucrose Broth (0.20) and Potato Dextrose Broth (2.09). For Aspergillus glaucus: Soybean Dextrose Broth (2.42), Groundnut Dextrose (2.42), Ofor (Detarium macrocarpum) Sucrose Broth (0.86), Sawdust Sucrose Broth (0.58) and Potato Dextrose Broth (1.66). The mean values in Soybean Dextrose Broth, Groundnut Dextrose and Ofor Sucrose Broth, are significantly $(\mathrm{P} \leq 0.05)$ higher than Sawdust Sucrose Broth and Potato Dextrose Broth. For Aspergillus niger: Soybean Dextrose Broth (3.15), Groundnut Dextrose (2.52), Ofor (Detarium macrocarpum) Sucrose Broth (0.81), Sawdust Sucrose

\begin{tabular}{|c|c|c|c|c|c|}
\hline ORGANISMS & SOYBEAN & GROUNDNUT & OFOR & SAWDUST & $\begin{array}{l}\text { POTATOES } \\
\text { (control) }\end{array}$ \\
\hline & \multicolumn{5}{|c|}{ DRY WEIGHT OF ORGANISMS in grams } \\
\hline \multirow[t]{3}{*}{ Aspergillus niger } & 3.815 & 2.607 & 0.709 & 0.769 & 2.299 \\
\hline & 2.233 & 2.061 & 0.901 & 0.708 & 2.045 \\
\hline & 3.411 & 2.909 & 0.821 & 0.732 & 2.379 \\
\hline \multirow{3}{*}{$\begin{array}{l}\text { Aspergillus } \\
\text { flavus }\end{array}$} & 2.454 & 2.304 & 0.213 & 0.204 & 1.583 \\
\hline & 3.589 & 2.692 & 0.156 & 0.096 & 2.377 \\
\hline & 2.347 & 2.178 & 0.412 & 0.323 & 2.326 \\
\hline \multirow{3}{*}{$\begin{array}{l}\text { Penicillium } \\
\text { chrysogenum }\end{array}$} & 2.566 & 1.846 & 0.405 & 0.358 & 1.801 \\
\hline & 2.478 & 2.313 & 0.804 & 0.554 & 1.465 \\
\hline & 2.286 & 1.299 & 0.752 & 0.537 & 1.054 \\
\hline \multirow{3}{*}{$\begin{array}{l}\text { Fusarium } \\
\text { oxysporium }\end{array}$} & 1.551 & 1.175 & 0.828 & 0.659 & 1.083 \\
\hline & 1.096 & 1.015 & 0.675 & 0.491 & 0.954 \\
\hline & 1.543 & 1.515 & 0.763 & 0.429 & 0.837 \\
\hline \multirow{3}{*}{$\begin{array}{l}\text { Rhizopus } \\
\text { stolonifer }\end{array}$} & 2.418 & 2.274 & 0.172 & 0.074 & 0.806 \\
\hline & 2.512 & 2.368 & 0.348 & 0.342 & 0.756 \\
\hline & 3.639 & 3.471 & 0.266 & 0.154 & 0.525 \\
\hline \multirow{3}{*}{$\begin{array}{l}\text { Aspergillus } \\
\text { glaucus }\end{array}$} & 2.744 & 2.451 & 0.916 & 0.664 & 1.906 \\
\hline & 2.378 & 2.213 & 0.863 & 0.568 & 1.594 \\
\hline & 2.148 & 2.066 & 0.826 & 0.514 & 1.491 \\
\hline \multirow{3}{*}{$\begin{array}{l}\text { Aspergillus } \\
\text { terreus }\end{array}$} & 2.389 & 2.332 & 0.86 & 0.115 & 1.332 \\
\hline & 2.469 & 2.114 & 0.965 & 0.156 & 1.304 \\
\hline & 2.882 & 2.391 & 0.942 & 0.356 & 1.141 \\
\hline
\end{tabular}

Table 1: Growth measurement of fungi in different growth media. 
Citation: Ikechi-Nwogu CG, Elenwo EN (2012) Comparative Evaluation of Growth Media for the Cultivation of Fungal Cultures. J Plant Pathol Microb 3:139. doi:10.4172/2157-7471.1000139

\begin{tabular}{|l|l|l|l|l|l|}
\hline TREATMENTS & $\begin{array}{l}\text { SOYABEANS } \\
\text { MEAN } \\
\text { VALUE }\end{array}$ & $\begin{array}{l}\text { GROUNDNUT } \\
\text { MEAN } \\
\text { VALUE }\end{array}$ & $\begin{array}{l}\text { OFOR } \\
\text { MEAN } \\
\text { VALUE }\end{array}$ & $\begin{array}{l}\text { SAWDUST } \\
\text { MEAN } \\
\text { VALUE }\end{array}$ & $\begin{array}{l}\text { POTATOES } \\
\text { (CONTROL) } \\
\text { MEAN } \\
\text { VALUE }\end{array}$ \\
\hline $\begin{array}{l}\text { Aspergillus } \\
\text { flavus }\end{array}$ & $2.7967^{\mathrm{a}}$ & $2.3913^{\mathrm{ab}}$ & $0.2603^{\mathrm{c}}$ & $0.2077^{\mathrm{c}}$ & $2.0953^{\mathrm{ab}}$ \\
\hline $\begin{array}{l}\text { Aspergillus } \\
\text { glaucus }\end{array}$ & $2.4233^{\mathrm{a}}$ & $2.2433^{\mathrm{ab}}$ & $0.8683^{\mathrm{a}}$ & $0.5820^{\mathrm{ab}}$ & $1.6637^{\mathrm{bc}}$ \\
\hline $\begin{array}{l}\text { Aspergillus } \\
\text { niger }\end{array}$ & $3.1530^{\mathrm{a}}$ & $2.5257^{\mathrm{ab}}$ & $0.8103^{\mathrm{ab}}$ & $0.7363^{\mathrm{a}}$ & $2.2410^{\mathrm{a}}$ \\
\hline $\begin{array}{l}\text { Aspergillus } \\
\text { terreus }\end{array}$ & $2.5800^{\mathrm{a}}$ & $2.2253^{\mathrm{ab}}$ & $0.9233^{\mathrm{a}}$ & $0.2090^{\mathrm{c}}$ & $1.2590^{\mathrm{cd}}$ \\
\hline $\begin{array}{l}\text { Penicillium } \\
\text { chrysogenum }\end{array}$ & $2.4433^{\mathrm{a}}$ & $1.8193 \mathrm{~b}^{\mathrm{c}}$ & $0.6537^{\mathrm{b}}$ & $0.4830 \mathrm{~b}$ & $1.4400^{\mathrm{c}}$ \\
\hline $\begin{array}{l}\text { Rhizopus } \\
\text { stolonifer }\end{array}$ & $2.8563^{\mathrm{a}}$ & $2.7043^{\mathrm{a}}$ & $0.2620^{\mathrm{c}}$ & $0.1900^{\mathrm{c}}$ & $0.6957^{\mathrm{e}}$ \\
\hline $\begin{array}{l}\text { Fusarium } \\
\text { oxysporium }\end{array}$ & $1.3967^{\mathrm{b}}$ & $1.3967^{\mathrm{c}}$ & $0.7553^{\mathrm{ab}}$ & $0.5263^{\mathrm{b}}$ & $0.9580 \mathrm{~d}^{\mathrm{e}}$ \\
\hline $\begin{array}{l}\text { Least } \\
\text { Significant } \\
\text { Mean }\end{array}$ & 0.9663 & 0.7404 & 0.1965 & $0.2049^{\mathrm{a}}$ & 0.4711 \\
\hline
\end{tabular}

The values above are means of three replicates. Means with the same letters are not significantly $(P \leq 0.05)$ different. $\rightarrow$ If $F$ calculated $>F$ tabulated, then the value is significant but $F$ calculated $<F$ tabulated, the value is insignificantTREATMENTS

Table 2: The mean value of fungi in different growth media.

Broth (0.73) and Potato Dextrose Broth (2.24). There is no significant difference $(\mathrm{P} \leq 0.05)$ between the mean values in all the broths. For Aspergillus terreus: The mean values in Soybean Dextrose Broth, Groundnut Dextrose and Ofor (Detarium macrocarpum) Sucrose Broth, are significantly $(\mathrm{P} \leq 0.05)$ higher than Potato Dextrose and Sawdust Sucrose Broth. For Penicillium chrysogenum: The mean values in Soybean Dextrose Broth, is significantly $(\mathrm{P} \leq 0.05)$ higher than those in other broths and Groundnut Dextrose broth, Ofor (Detarium macrocarpum) Sucrose Broth and Sawdust Sucrose Broth values are significantly $(\mathrm{P} \leq 0.05)$ higher than that of Potato Dextrose Broth. For Rhizopus stolonifer and Fusarium oxysporium: The mean values in Potato Dextrose Broth are significantly $(\mathrm{P} \leq 0.05)$ lower than those in other broths. The mean values in Ofor (Detarium macrocarpum) Sucrose Broth is significantly $(\mathrm{P} \leq 0.05)$ higher than those in Soybean Dextrose Broth, Groundnut Dextrose and Sawdust Sucrose broth respectively.

\section{Discussion}

From the results obtained, Soybean Dextrose Broth performed better than other media. The difference in the performance is probably due to the fact that soybean contains more vitamins and minerals that have been identified as vital to fungal growth. Nutritionally, soybean is best known for its high carbohydrate, protein, sugar fiber, fat and other nutrients. The second best medium was Groundnut Dextrose Broth. Organisms in this broth grew well probably due to its nutritional content. It has higher calcium, potassium etc and contains Cystine, Thiamine (Vitamin $\mathrm{B}_{1}$ ), Riboflavin (Vitamin $\mathrm{B}_{2}$ ), Niacin (Vitamin $\mathrm{B}_{3}$ ), Pantothenic acid $\left(B_{5}\right)$, Folate $\left(\right.$ Vitamin $\left.B_{9}\right)$, which are absent in others.

The cooked whole Ofor, when plated using standard blotter also had good fungal growth but the broth did not support so much growth. Ofor (Detarium macrocarpum) was assessed chemically for the presence of some antinutritional factors such as; oxalate, phytate, saponin and tannin. And it was discovered that it contains these chemicals in different proportions as shown below.

Levels of antinutritional factors in Detarium macrocarpum in percentage (\%) [7].
Oxalate
$13.50 \pm 2.16$
Phytate
$2.13 \pm 0.97$
Saponin
$12.10 \pm 0.05$
Tannin
$3.54 \pm 0.28$

Considerable interest has been generated by recent studies on the chemical composition of some wild fruits in Nigeria. Some of these wild fruits have higher nutritional values compared with levels found in cultivated fruits. However, some of these fruits contain antinutritional factors that can affect the availability of nutrients required by the body. The antinutritional factors interfere with metabolic process so that growth and bioavailability of nutrients are negatively influenced.

These chemicals found in Ofor (Detarium macrocarpum) contain antinutritional factors that affected the availability of nutrients required by the body of the fungi so their growth rates were inhibited.

In conclusion, evaluating the suitability of these growth media, soybean was the best medium for the growth of the fungi evaluated. As a recommendation, Soybean dextrose should be used as a medium for fungal growth considering these evidences shown above and it might be necessary to screen more fungi using Soybean dextrose.

\section{References}

1. Alexopoulos CJ, Mims CW, Blackwell M (1996) Introductory Mycology. John Wiley and Sons, New York.

2. Ataga AE, Elenwo EN, Nwachukwu EO (2010) Laboratory Exercises and Series in Mycology. ACOTEC Technology, PH, Nigeria.

3. Ikechi-Nwogu CG, Elenwo EN (2010) Evaluating Some Growth Media for the Cultivation of Fungal Cultures. MSc thesis, Department of Plant Science and Biotechnology, University of Port Harcourt, Nigeria.

4. (2009) The Free Encyclopedia-Fungus.

5. Thomas JV (2000) The Kingdom Fungi. Department of Biology. University of Wisconsin-La Crosse, USA

6. Umaru HA, Adamu R, Dahiru D, Nadro MS (2006) Levels of Antinutritional Factors in Some Wild Edible Fruits of Northern Nigeria. African Journal of Biotechnology. 6: 1935-1938.

7. Umechuruba Cl, Elenwo EN (1996) Introductory Mycology Question and Answer Approach. Pen Paper Publication, Owerri, Nigeria. 